УДК: 94(477)(-25)(1943)

DOI: $10.33099 / 2707-1383-2021-41-3-110-131$

\title{
Aleš Binar
}

Ph. D., Associate Professor of Department

of Military Theory of Faculty of Military

Leadership of University of Defence

(Brno, Czech Republic)

ORCID: https://orcid.org/0000-0001-8271-3730

Email:ales.binar@unob.cz

\section{PARTICIPATIONOFCZECHOSLOVAKSINTHE BATTLE OFKYIV 1943}

In the Battle of Kyiv, 1st Czechoslovak Independent Brigade took its part in Soviet offensive of 1st Ukrainian Front. The brigade itself was formed in May 1943 and the battle was its first operational deployment. The goal of the study is to give a description of formation of brigade, its organization, and its participation in Kyiv offensive in broader context; that is why also overall goals of Soviet offensive and the course of the battle as well as other moments from Czechoslovak military tradition are taken into account. Also, since the Battle of Kyiv was the first Czechoslovak experience with urban warfare, its deployment is view according to the principles of combat in urbanized terrain. This attitude allows to assess the contribution of Czechoslovaks in the offensive. Methodologically, the study derives from procedures of historiography, especially archival research, i.e. its conclusions come out from critical appraisal of archival documents. These are war journals, operational orders, combat reports, and situational maps that are deposited in Czech Military Archives in Prague.

Key words: Battle of Kyiv; 1st Czechoslovak Independent Brigade; Eastern Front; Second World War; 1943; urban warfare; military tradition.

The Battle of Kyiv that lasted from 3 to 13 November 1943 belongs to the decisive moments of the Second World War and without any doubts represents a key victory of the Red Army in a territory of Ukraine, both in operational-strategic and in symbolic sense. The battle itself is also part of Czech and Czechoslovak military tradition because of participation of 1st Czechoslovak Independent Brigade (1. československá samostatná brigáda).

This introduction also defines the aim of the study. Its goal is to give a description of Czechoslovak involvement in the Battle of Kyiv and an analysis of deployment 
of Czechoslovak Brigade from operational and tactical point of view, especially with regard to principles of urban warfare. The reason is to assess a contribution of Czechoslovak forces for result and course of the battle which is aspect that previous studies and books usually omitted (see below).

To achieve this, it is necessary to gain facts of 'what really happened' in first place. The study proceeds from historiographic literature, however, its core is based on thorough research in archives. Documents of the Czechoslovak Brigade are depositedintheCzechMilitaryHistorical Archives in Prague (Vojenský ústředni archiv-Vojenský historický archiv; VÚA-VHA) and its two main funds; the first one is eponymous collection of documents of 1st Czechoslovak Independent Brigade, the second one, then, the Czechoslovak Tank Units in the USSR (Československé tankové jednotky $v$ SSSR). Supplementary pieces of information could be found in the fund Czechoslovak Military Mission in the USSR (Československá vojenská mise $v$ SSSR). Pertaining to archival documents, the key value belongs to war journals of brigade and its subordinated units, combat reports, and operational orders; irreplaceable are, finally, maps that depicts the situation in battlefield and development of the fights majority of them was worked out after the combat ended, so they represent in fact a combat summary.
Primary resources represent, then, memoirs of participants. A book titled 'From Buzuluk to Prague' (Svoboda, L. 1960, 305 p.) of Col. Ludvík Svoboda, commander of the brigade, became in number of aspects a 'canon' of interpretation of the events during communist era in Czechoslovakia (1948 to 1989). Lt. ${ }^{1}$ Josef Buršík, on the other hand, despite being decorated Hero of Soviet Union, became persona non grata and left for exile after communist coup d'état in Czechoslovakia; he named his memoires 'Do not Regret your Sacrifice' (Buršík, J. 1992, 125 p.). These are followed by other participants and leaders in the battle, e.g. Lt. Oldřich Kvapil or Private Josef Boldiš (Kvapil, O. 2010, 307 p.; Směr Praha. 1960, p. 89-92).

The study tries to prove, as it is given further, that deployment of the Czechoslovak Brigade in the Battle of Kyiv was one of the most successful combats of Czechoslovak armed forces in the USSR during the Second World War. In contrast to this evaluation, the attention of Czech and Czechoslovak historiography does not seem to be adequate. The reason is that from Czechoslovak point of view,

1 Ranks equivalent between $\mathrm{Czech} / \mathrm{Czecho-}$ slovak and English use and nomenclature could be only approximate, especially among lower hierarchy of commissioned officers; it is a case of translation of ranks podporučik and nadporučík (both lieutenant; the first mentioned, however, could be also translated as a first lieutenant) or štábní kapitán (literally 'staff captain', rank between captain and major). 
the battle stands in the shadows of the Battle of Sokolovo (Соколове, Kharkivska oblast), the very first Czechoslovak battle in the USSR, and the Battle of Dukla Pass during which Czechoslovaks crossed borders of their own state. However, there is a number of texts devoted to the topic. The newest one is a study from 2013 (Vališ, Z. 2013, p. 46-62) but it does not bring no new pieces of information nor exceeds previous titles in interpretation. That is why irreplaceable value still belongs to much older books, which some of them dates in 1950s; despite being biased (pro-communist regime), with critical approach they bring remarkable quantity of facts (Za svobodu Československa. Svazek první. 1959, 487 p.; Kyjev. Dukla. Praha. 1975, 331 p.). Other primary and secondary resources are of additional value and as such are quoted continuously in the text.

\section{Czechoslovak Armed Forces in the USSR}

Czechoslovakia lost its independence in March 1939 when its territory was occupied by Nazi Germany. Czechoslovaks, however, did not accept this situation and their effort to restore national and state sovereignty resulted in formation of exile government with its seat in London. The government gained international recognition and began to form its own armed forces in territory of allied countries, and finally in the Soviet Union. The first unit was 1st Czechoslovak Independent (Field)
Battalion (1. československý samostatný [polni] prapor) that was involved in the Battle of Sokolovo in March 1943; the battle itself was negligible from operational viewpoint but gained propagandistic appraisal when became represented as a 'brotherhood sealed with blood' between Czechoslovaks and Soviets (Fidler, J. 2003, p. 35-36).

In summer 1943, Czechoslovak armed forces in the USSR were reorganized into 1 st Czechoslovak Independent Brigade. The brigade was established in Novokhopyorsk (Новохоперск/Новохопёрск), some $300 \mathrm{~km}$ east of Voronezh, on 30 May 1945. Col. L. Svoboda was appointed as its commander with Lt. Col. Vladimír Prikryl to be his deputy; the chief of staff was Cpt. Bohumír Lomský (Lenc). Since the brigade was formed as an 'independent', there were all key military branches of ground forces within its organization. Its key component were two infantry battalions, each of them of six companies, i.e. of three infantry, one machine-gun, one mortar and of one anti-tank; then, there was a tank battalion that was composed of four companies, i.e. of middle tanks (T-34), light tanks (T-70), armoured cars (BA-64), and of sub-machine guns (PPSh-41). Fire support provided two artillery battalions - one of howitzers $(122 \mathrm{~mm})$ and one of canons $(76 \mathrm{~mm})$ -, battery of anti-tank canons (45 mm), and company of heavy anti-aircraft machine-guns $(12.7 \mathrm{~mm})$. Combat support represented engineering 
company, signal company and other rear and staff units.

By 30 September 1943, there were 3,309 men in the brigade, among them 105 officers and 896 non-commissioned officers. Czechoslovaks, however, lacked enough drivers. That is why 174 Red Army men served in Czechoslovak forces too. The brigade was equipped with ten tanks T-34, ten tanks T-70, ten armoured cars BA-64, six howitzers (122 mm), 22 anti-tank canons (twelve of $76 \mathrm{~mm}$, ten of $45 \mathrm{~mm}$ ), 30 mortars (twelve of $82 \mathrm{~mm}$, eighteen of $50 \mathrm{~mm}$ ), four anti-aircraft guns $(37 \mathrm{~mm})$, twelve anti-aircraft machine-guns $(12.7 \mathrm{~mm})$, 43 anti-tank rifles, 110 machine-guns, 467 sub-machine guns, and 2,133 rifles $\mathrm{SVT}^{2}$.

The key problem in formation of Czechoslovak military units in the Soviet Union were human resources. The Volhynia, the territory that lived thousands of Czechs, were by that time occupied by Germans. It meant that the only 'available' Czechoslovaks in the USSR were members of socalled Legion of Czechs and Slovaks ${ }^{3}$ that was captured by Red Army during September Campaign of 1939 and spent two years in internment, then there

\footnotetext{
2 VÚA-VHA, archival fund [a. f.] Československá vojenská mise v SSSR [Czechoslovak Military Mission in the USSR], box 8, inv. no. 67.

3 The Legion of Czechs and Slovaks (Český a slovenský legion; officially Legion Czechów $i$ Słowaków) was a short-living military unit that was formed in Poland in September 1939; it had approximately a thousand members.
}

were prisoners of 'Gulag' and finally communist emigration, small group of politicians and functionaries that lived in Moscow.

In respect of experience, composition of the brigade was far to be unified. The core of the formation represented Czechoslovak volunteers and conscripts who enlisted the Czechoslovak exile army in the Soviet Union in 1942, i.e. members of former Legion of Czechs and Slovaks and some Ruthenians (Ukrainians) $)^{4}$ released from Gulag. By late-1943 they were skilled soldiers with combat experience. The largest group among Czechoslovak soldiers were, however, Ruthanians, who left Gulag prison too late to take part in combat in early 1943 and who were placed into brigade in late 1942 and during 1943. The last distinctive

4 The issue of Ruthenians belongs to one of the most complicated moments in Czechoslovak history. Subcarpathian Ruthenia (Podkarpatská Rus; after 1944-1945 Zakarpatská Ukrajina, Transcarpathian Ukraine) was integral part of Czechoslovakia until 1938-1939. After that, its territory was occupied by Hungary. A lot of Ruthenians, however, disagreed with that and in the moment, Hungary began to force them to enlist into armed forces, they rather left for the Soviet Union. In the USSR, however, they were treated for unlawful crossing of the borders and were sentenced to years in prison in Gulag. Their exact numbers are up today unknown. It is estimated that there were 10,000 of them, but lot of them died in $\mathrm{Si}$ beria before they could replenish Czechoslovak army. The next issue pertains their nationality; they, themselves, did not identified as Ukrainians, but mostly as Ruthenians (Rusini); these, however, rapidly changed and during the course of war most of them accepted Ukrainian identity. 
group represented officers who were members of Czechoslovak army that was formed in the United Kingdom and were transferred to the USSR. Some of them, like Lt. Col. V. Přikryl, deputy commander, had combat experience from the Battle of France, some of them, like Cpt. Josef Kholl, commander of II battalion, gained their combat experience in desert during the Siege of Tobruk, but there were also others, like Lt. Col. Gustav Krátký (Krautstengel), commander of tank battalion, who had none (Vojenské osobnosti československého odboje. 2005, p. 131-132, 149, 242-243).

The Czechoslovak brigade was also multi-national military formation. Except Czechs and Slovaks there were Ruthenians - Ukrainians; in fact, they composed its majority reaching approximately two thirds (sic!) of its numbers (Maršálek, Z. 2017, p. 394402; Binar, A. 2020, p. 458-472).

All in all, there was in fact only one thing that was in common for members of the Czechoslovaks Brigade and it was their disagreement with communist ideology and Soviet politics (except of Red Army men and small group of Czechoslovak communists, of course); but in 1943, there was, however, the only one option to gain national independence, and it was to fight side by side with Soviets. Despite this political issue, the moral of members of the Czechoslovak Brigade was high, especially later when they awaited an order to attack Kyiv.
According to war journal, most of them expected that battle is going to be a decisive moment of the whole war and Nazi Germany would be finally defeated. Their motto sounded 'To Kyiv for Prage' 5 .

The training of the brigade lasted mainly from June to midSeptember 1943. On 12 September 1943, the brigade was given a banner and carried out the final exercise that was observed by Soviet Marshall Georgy Zhukov, deputy commander in chief of the General Staff. After evaluation of the results of the exercise, the brigade was found to be operational and was given an order for combat deployment.

The brigade was, then, transferred via railway through Voronezh and Kursk to Pryluky (Прилуки). The $800 \mathrm{~km}$ journey that lasted 12 days did not go without a hitch; the Luftwaffe raid to a train loaded with Czechoslovak artillery units claimed loss of 108 men and two howitzers on 12 October 1943. Remaining $150 \mathrm{~km}$ from Pryluky to Kyiv the brigade marched on its own. Finally, when brigade got close to Ukrainian capital, it was ordered to cross the Dnieper River and to reach an area of Lyutizh (Лютіж), some $30 \mathrm{~km}$ north of Kyiv; there, the brigade took its positions in wooded area on 23 and 24 October 1943 (Vojenské

VÚA-VHA, a. f. 1. československá samostatná brigáda [1st Czechoslovak Independent Brigade], box 1, inv. no. 10 . 
dějiny Československa. IV. díl (19391945). 1988, p. 327-331).

In Dnieper bridgehead, the brigade was subordinated to 1st Ukrainian Front that was just renamed (on 20 October 1943) from its designation 'Voronezh Front'. Its commander was Army Gen. Nikolai Vatutin. He decided to put the brigade into the composition of 38th Army of Lt. Gen. Kirill Moskalenko (who took its command on 27 October 1943; he replaced Col. Gen. [Lt. Gen.] Nikandr Chibisov) (Za svobodu Československa. Svazek první. 1959, p. 302-318).

\section{Operational and Tactical Goals of the Kyiv Offensive}

In second half of 1943, the Germans got into strategic defensive in the Eastern Front. Despite achieving victory in the Third Battle of Kharkov, they suffered severe defeat and considerable losses in the Battle of Kursk and subsequently were not capable to withstand Soviet increasing superiority in numbers and material and in initiative. By the end of the Kursk Battle, Soviets launched two large offensives and pushed Germans back to Dnieper. Soviet high command was concerned that the river could be suited as a strong defence line and Germans could trench themselves on its banks. That is why Red Army executed harsh effort to gain bridgeheads on its west bank before the outbreak of winter. That is why the so-called Battle of Dnieper that consisted of number of Soviet campaigns took place on 26 August to 23 December 1943 (Citino, R. M. 2012, p. 198-237).

The operation to liberate Kyiv and to destroy German forces in its area already started in October 1943 when Army Gen. N. Vatutin decided to lead an attack from bridgehead in Velykyi Bukryn (Великий Букрин), some $90 \mathrm{~km}$ south-east of the city. But after a couple of unsuccessful attempts and weeks of exhausting combat without any result, the Stavka, the Soviet supreme command, ordered to transfer the main effort to northern bridgehead around Lyutizh.

The bridgehead in Lyutizh was much closer to Kyiv, was less defended and - which was decisive - Soviets correctly assumed that Germans would not expect any main offensive there. According to their assessment, they expected that decisive effort would have taken place downstream of Dnieper near Kryvyi Rih (Кривий Ріг) and Melitopol (Мелітополь). They thought that the Red Army would have made use of its previous advancement to cut off German 6th and 1st Tank Army in Southern Ukraine (Schramm, P. E. 2005, p. 1217-1243). As Field Marshall Erich von Manstein added after the war, he was uncertain even about goals of Soviets in Dnieper area (Manstein, E. 1964, p. 553-554).

But the bulk of forces of 1 st Ukrainian Front was on its southern wing. It meant that to fulfil the order of Stavka it was necessary to undergo massive regrouping without being spotted 
by German reconnaissance; but Soviets managed to do so between 25 October and 2 November 1943. To distract their opponent, 27th and 40th Army launched relief attack from Bukryn bridgehead on 1 November 1943 (Vtoraya mirovaya voyna, 1939-1945 gg. 1958, p. 480483; Zhukov, G. K. 1979, p. 177-178).

The task to attack from bridgehead in Lyutizh was given to 38th and 3rd Guards Tank Army. Thirty Eighth Army should have assaulted from line between Vyshhorod (Вишгород) and Moshchun (Мощун), circumvented Kyiv from west and continued in line Pushcha-Vodytsya

(Пуща-Водиця) and Sviatoshyn (Святошин) and then in direction to Vasylkiv (Васильків). The main combat effort should have been carried out in area of contact of its 50th Rifle and 51st Rifle Corps. Third Guards Tank Army of Lt. Gen. Pavel Rybalko represented the second wave in Soviet offensive plans; after penetrating through German defence, its goal was to reach Fastiv (Фастів), ca. $90 \mathrm{~km}$ south-west of Kyiv, and then Bila Tserkva (Біла Церква). The last formation of Lyutizh bridgehead, 60th Army of Lt. Gen. Ivan Chernyakhovsky, had its task to protect rear and right flank of 38th and 3rd Guards Tank Army by attacking in direction to Rovy (Рови) and Dymer (Димер).

Opening of the offensive was, nevertheless, continuously delayed before 3 November 1943 was ultimately set as its beginning (Dějiny druhé světové války 1939-1945. Svazek 7. 1980, p. 234-239).

Originally, the Czechoslovak Brigade was ordered to inflict cover assault in north, north-west and south-west direction in line of Demydiv (Демидів), Synyak (Синяк), Huta-Mezhyhirska (Гута-Межигірська) and Moshchun (Za svobodu Československa. Svazek první. 1959, p. 318-326). But according to new operational aims from 24 October 1943, the brigade was reassigned and as a result of commander meeting that took place five days later, Army Gen. N. Vatutin decided to send it in the main direction within composition of 51st Rifle Corps (Svoboda, L. 1960, p. 135-136) ${ }^{6}$. Exact task as well as line of advancement for the brigade was not specified in that meeting. Both was set later and depended on the development in the battlefield. Final assignment was later formulated in operational order of brigade no. 7 that was issued in the morning on 5 November 1943. According to this, brigade should have attacked southwards from area of Children Sanatorium (south-east of Pushcza Vodytsya), then continued through area west of Syrets (Сирець) and village Voleykiv (Волейків), and finally turn to south-east roughly alongside Brest-Litovsk Street (today Prospect Peremohy, Проспект

6 According to interpretation that prevailed during communist era in Czechoslovakia, deployment of Czechoslovak in main offensive direction was result of personal initiative of brigade commander, Col. L. Svoboda. 
Перемоги) into railway station (KyivPasazhyrskyi, Київ-Пасажирський). The centre of effort of 1st Czechoslovak Brigade was set to be on its right wing that was entrusted to first and tank battalion; on the left should have advanced II battalion?

The time gained due to delay of the offensive Czechoslovaks made use for additional training. Despite expecting fights within streets of Kyiv, the training was, however, solely focused on combat in woods 8 ; this omission, luckily for Czechoslovaks, proved not to be fatal (see next). ${ }^{9}$

For Kyiv Operation, 1st Ukrainian Front had 663,000 men in disposal together with 7,000 pieces of artillery, 675 tanks and self-propelled guns, and 700 planes. It means that Czechoslovak Brigade compose roughly two hundredths of all Red Army power. Together, German Army Group 'South' that was responsible for Eastern front in range from Kyiv to southern Ukraine, had approximately 719,000 Mann, 271 tanks and self-propelled guns and 2,263 guns. But only a smaller part of them were placed opposite Lyutizh bridgehead. Aerial support provided

7 VÚA-VHA, a. f. 1. československá samostatná brigáda [1st Czechoslovak Independent Brigade], box 1, inv. no. 10a.

8 VÚA-VHA, a. f. 1. československá samostatná brigáda [1st Czechoslovak Independent Brigade], box 1, inv. no. 10 .

9 In some older titles there is mentioned that Czechoslovaks trained also for urban combat. But it seems to be an additional attempt to make their preparation look more focused.
Air Fleet 4 with 562 planes, but its strength was divided between two army groups, 'South' and 'A' (Das Deutsche Reich und der Zweite Weltkrieg. Band 8. Die Ostfront 1943/1944. 2007, p. 367-372). In Lyutizh bridgehead, the Soviets had three times more men than Germans, four and a half in guns and mortars and nine times in tanks; Soviets also reached the highest concentration of fire power for main attack so far and had aerial superiority (Dějiny druhé světové války 19391945. Svazek 7. 1980, p. 240).

\section{Battle Order}

Thirty Eighth Army of 1st Ukrainian front was composed of five corps. In the frontline, there were 51st Rifle Corps on the right and 50th Rifle Corps on the left wing of the army; the first one with 180th Rifle, 240th Rifle and 136th Rifle Division, the second one with 167th Rifle, 232nd Rifle, 163rd Rifle, 71st Rifle and 340th Rifle Division; except these formations, 51st Rifle Corps had 1st Czechoslovak Brigade in its reserve and 50st Rifle Corp its 74th Rifle Division. Behind the frontlines, there were 21st Rifle, 23rd Rifle and 5th Guards Tank Corps as well as number of artillery units in reserves of 38th Army. The most powerful force that remained in rear was, however, 3rd Guards Tank which had two tank (6th Guards and 7th Guards) and one mechanized (7th Guards) corps, and then, 1st Guards Cavalry Corps.

In a moment Czechoslovaks were deployed, they assumed their positions 
in the centre of 51st Rifle Corps of Maj. Gen. Pyotr Avdeenko while 240th Rifle Division (Col. Terentiy Umanskiy) and its Rifle Regiment 931 became its left neighbour and 136th Rifle Division (Maj. Gen. Ivan Puzikov) was on its right. The II infantry battalion of Cpt. J. Kholl took place on the left and I infantry battalion of Maj. Miloslav Kukla on the right wing and tank battalion remained in rear; both infantry battalions were reinforced with one antitank battery, one platoon of engineers and one platoon of anti-aircraft machine-guns each, while I battalion, moreover, was given direct fire support of I artillery battalion. Companies of tank battalion should have been deployed in fact independently and acted in mutual cooperation or in cooperation with infantry; it was a task of middle tank company of Lt. J. Buršík, light tank company of Lt. Richard Tesařík and sub-machine company of Lt. Antonín Sochor ${ }^{10}$ (Moskalenko, K. S. 1972, p. 159).

In area of Lyutizh bridgehead, Germans deployed two army corps of 4th Tank Army; an area surrounding Hostomel (Гостомель) north-west of Kyiv was defended by 340th Infantry, 327th Infantry, 208th Infantry, and 68th Infantry Divisions of XIIIArmy Corps of Artillery Gen. Arthur Hauffe, and Kyiv itself by VII Army Corps of Infantry Gen. Anton Dostler

10 VÚA-VHA, a. f. 1. československá samostatná brigáda [1st Czechoslovak Independent Brigade], box 1 , inv. no. 10a. with its 75th Infantry, 88th Infantry, 323rd Infantry, and 213rd 'Security' Division. In reserve, Germans had three division; west of Hostomel there was located 8th Panzer Division, in Kyiv 7th Panzer Division and westwards of city 20th Panzer Grenadier Division. During their advancement, Czechoslovaks met 75th Infantry Division and probably also several units of the 88th Infantry Division that were reinforced with tanks of 7 th Tank Division $^{11},{ }^{12}$.

\section{Advancement towards Kyiv}

Artillery fire that commenced the Battle of Kyiv opened on 3 November 1943. By that time, the Czechoslovak Brigade remained in rear but its howitzer batteries took part in shelling of German positions. Fire preparation was enormous but focused on narrow corridor in area where 51st Rifle Corps bordered with 50th Rifle Corps. Brigade itself began to march towards front line in the evening of the first day of operation with its task to attack Vyshorod together with 180th Rifle Division. This order was, however, cancelled since Germans retreated without fight. Instead of this, the brigade was directed to area of Children Sanatorium where harsh combat between the Red Army

${ }^{11}$ Bundesarchiv-Militärarchiv, a. f. Reichsheer-Heer 2KART [Empire Ground Forces Ground Forces], map 7400.

${ }^{12}$ Since German divisions swiftly changed their positions by the time the battle began, present state of knowledge cannot allow to determine exactly which units Czechoslovak encountered. 
and Germans took place. But when soldiers from reconnaissance units arrived, they noticed that Germans had withdrew; that is why only one company that managed to break into depth of German defence got involved into direct combat during the night from 4 to 5 November 1943.

Final order specifying the tasks of Czechoslovak in the battle arrived in the morning on 5 November 1943. Commander of 51st Rifle Corps tried to made use of advancement of its right neighbour and assigned the brigade to reach Kyiv's suburb and then to advance to area of railway station until the end of day. Czechoslovaks burst forth at 9.20 a.m. ${ }^{13}$.

Initial advancement of Czechoslovak brigade and its two infantry battalions was fast as well as of tank battalion that charged later at 1.10 p.m. Tanks also transported members of submachine company as so-called infantry tank riders. After some 50 minutes and ca. four kilometres Czechoslovak encountered their first obstacle, antitank ditch with mine field that stretched between suburb Pryorka (Приорка) and Svyatoshin. Behind the ditch, Germansdugtrenchesthatweredefended by infantry with artillery support; in a moment Czechoslovaks reached the ditch, they got into heavy mortar and cannon shelling. Czechoslovak tanks together with anti-tank cannons

13 VÚA-VHA, a. f. 1. československá samostatná brigáda [1st Czechoslovak Independent Brigade], box 1, inv. no. 10 . returned fire; under its cover, submachine gunners with engineers cleared passages through, especially removing mines and destroying ditch walls by explosives (Směr Praha. 1960, p. 91). Joint pressure of sub-machine gunners and counterfire forced Germans to retreat. But while I battalion that had tanks support managed to get over the ditch sometimes before 2.00 p.m., II battalion got involved in harsh fights that slowed its movement ${ }^{14}$.

After overcoming the ditch, first and tank battalion restored their rapid tempo until reached hills north of Dekhtyari (Дехтярі) and then a railway ravine near Brest-Litovsk Street around 2.00 p.m. The only way for tanks to cross it was to use bridge over railway that was heavily protected. Tanks themselves were not suitable for this task since in narrow space without possibility of manoeuvre the threat of their destruction was very high. Sub-machine company of Lt. A. Sochor, however, bypassed Germans from right and assault their flank. As soon as German positions were cleared, tanks drive into bridge and advanced toward Kyiv. They reached Brest-Litovsk Street around 4.00 p. m.

Advancement of II battalion was distinctly much slower. Except delay during overcoming anti-tank ditch, its left flank got opened since

${ }^{14}$ VÚA-VHA, a. f. 1. československá samostatná brigáda [1st Czechoslovak Independent Brigade], box 1, inv. no. 10. 
its neighbour, 240th Rifle Division encountered harsh resistance in suburb Priorka and could not catch up with the rest of Czechoslovaks (Kyjev. Dukla. Praha. 1975, p. 42-43). Then, II battalion became entangled in combat in a village near Syrets (Сирець). After that, in camp east of Syrets, the battalion was struck by heavy shelling from fortified positions of Germans. That is why the company of light tanks was ordered to turn sharply left and support Czechoslovak infantry. Assault of tanks that aimed in flanks of opponent reached moment of surprise and Czechoslovaks managed to break German resistance at about 5.00 p.m.; thus, also the II battalion reached Kyiv near the end of Brest-Litovsk Street sometimes after 6.00 p.m. ${ }^{15}$.

\section{$*$}

The advancement of the Czechoslovak Brigade in that phase of the battle was conditional on the achievements of the right wing of 50th Rifle Corps, namely its 136th Rifle Division, as well as left wing of 51st Rifle Corps and its 167th Rifle Division that already by 3.00 p.m. attacked Svyatoshyn (Святошин) and, later on by 6.00 p.m., together with 232nd Rifle Division, 7th Guards Tank and 5th Guards Tank Corps took Chokolyvka (Чоколивка). In its result Germans lost their main road and railway retreat ways from Kyiv

15 VÚA-VHA, a. f. 1. československá samostatná brigáda [1st Czechoslovak Independent Brigade], box 1 , inv. no. 10 . and the threat of encirclement became imminent. By that time, also 23rd Rifle and 21st Rifle Corps that were previously in the rear were deployed with their task to enforce Soviet attack on the right wing of 1st Ukrainian Front. So, this moment of the battle proved to be crucial and Soviet command had profited from the fact that managed to gather powerful reserves north of Kyiv, especially tank units (Moskalenko, K. S. 1972, p. 152166). Also, German command admitted that it became evident that Kyiv was going to be lost (Manstein, E. 1964, p. 554).

\section{Combat in Kyiv}

At the head of advancement of I battalion there was its 1st company and partially also 3rd company. After reaching Brest-Litovsk Street around 4.30 p.m., battalion advanced independently through suburb on the right side of street. There, Czechoslovaks cooperated with Red Army tanks that were ahead before 136th Rifle Division and thus without infantry support. Around 5.45 p.m., I battalion reached compound of military academy, ${ }^{16}$ present-day main building of Ivan Chernyakhovsky National Defence University of Ukraine.

${ }^{16}$ In archival documents, however, the compound is referred to as the Ground Forces College (pěchotní učiliště). But in fact, before being evacuated in 1941, the official name of military academy was the 1st Kyiv Artillery School (The National Defence University of Ukraine named after Ivan Cherniakhovskyi. General Information. 2021). 
In its area, I battalion finished its advancement.

In eastern suburb of Kyiv, Germans built a stronghold in 'Bolshevik' Factory on the right side (in downtown direction) of Brest-Litovsk Street. The task to eliminate German resistance belonged to company of middle tanks. Initially, the fights were harsh since defenders were well positioned and hidden. But Czechoslovak got luck. During combat, they were contacted by two Ukrainian women who new location of German positions; this 'intelligence' support made conquering of factory compound significantly easier. Czechoslovak tanks, then, broke through main gate and according to gained knowledge silenced German resistance around 5.00 p.m. (Buršík, J. 1992, p. 52).

Couple of hundreds of meters next to 'Bolshevik', another stronghold emerged before Czechoslovaks, this time in left side of Kyiv main street in compound of film factory. A tank platoon of T-34s managed to advance in vicinity of $\mathrm{ZOO}$ garden that was located down the street but was repelled by defenders. Czechoslovaks were forced to halt their attack until another tank platoon together with platoons of sub-machines, reconnaissance and engineers bypassed German positions from north and went through $\mathrm{ZOO}$, thus finishing the encirclement of film factory at around 6.00 p.m. Germans, nevertheless, spotted this manoeuvre and managed to retreat without being caught in a pocket ${ }^{17}$.

After that, Czechoslovaks continued in rapid pace since German began retreating and limited their resistance to rear patrols. But tank and reconnaissance companies advanced independently and in the streets of Kyiv lost contact to each other. In one moment, reconnaissance platoon of II battalion continued down the city, while sub-machine company of tank battalion turned sharply, thus advancing directly to each other. Both units met ca. 150 meters north of an area of railway station but were not aware of each other allegiance. Thus, a gunfight broke out. Members of tank battalion, nevertheless, overheard shouts of submachine gunner and realized true identity of their opponents (Kvapil, O. 2010, p. 248-249). After that, both companies, now accompanied also with reconnaissance platoon, continued in their advancement and by 7.00 p.m. reached railway station.

Around 6.00 p.m., also company of light tanks began its advancement down the Kyiv main street with its aim to reach main passenger trains station. Its T-70s encounter number of defence positions but at 8.00 p.m. arrived in area of train station. By the same time also company of middle tanks

17 VÚA-VHA, a. f. Československé tankové jednotky v SSSR [Czechoslovak Tank Units in the USSR], box 1, inv. no. 12. 
as well as sub-machine company reach its goal ${ }^{18}$.

Loss of awareness of location of small units such a company, as Czechoslovaks experienced, was nothing unusual deep in streets of Kyiv. Czechoslovaks recall a moment when a unit of Soviets tanks rolled from west and in a couple of minutes later its commander discussed following course of action together with Czechoslovaks; this commander was Lt. Gen. Andrey Kravchenko and marching tanks belonged to his 5th Guards Tank Corps, probably to 22nd Tank Brigade. The most probable route of Soviet tanks was through Borshchahivska (Борщагівська; its western part is present day Prospekt Kosmonavta Komarova, Проспект Космоавта Комарова) ${ }^{19}$. Exact location of this unusual meeting between Soviet and Czechoslovak commanders is not certain, but it must have been in vicinity of train station. The most important is, however, the fact that both sides got surprised; neither of them expected to meet anyone else but Germans. Luckily, this time friendly fire did not

${ }^{18}$ VÚA-VHA, a. f. Československé tankové jednotky v SSSR [Czechoslovak Tank Units in the USSR], box 1, inv. no. 12.

${ }^{19}$ In his memoirs, Oldřich Kvapil states that Soviet tanks came along Zhytomyr road. There were, however, two streets that could be referred to as Zhytomyr road, i.e. Brest-Litovsk Street and so called Old Zhytomyr Street (present day Dehtyarivska, Дегтярівська), but neither of both fits the description of combat situation in battlefield. burst out. On contrary, the result of this accidental encounter was mutually beneficial, because Red Army tanks drove their adversaries off train station area while Czechoslovak participated as reconnaissance (Burš́́k, J. 1992, p. 52-53; Kvapil, O. 2010, p. 250-251).

The last Czechoslovak unit that arrived in its designated goal was II battalion whose companies reached the area around train station from north one by one between 7.00 p.m. and 10 p.m.

Fulfilling its combat task cost Czechoslovak 89 lost men; 24 were killed in action, 60 were wounded and five were listed as missing in action; 37 of them belonged to I battalion, 28 to II battalion, 18 to tank units and six to engineer units. Much severe losses, however, pertained to heavy equipment; out of initial 20 tanks $^{20}$ only 11 remained fully operation, i.e. four $\mathrm{T}-34 \mathrm{~s}$ and seven T-70s (Za svobodu Československa. Svazek první. 1959, p. 359). Commander of the brigade, Col. L. Svoboda, estimated that Czechoslovaks killed some 630 German soldiers and officers without counting defenders of destroyed strongholds and gained eleven prisoners of wars ${ }^{21}$.

${ }^{20}$ Out of 20 tanks, however, 18 were operational, two were by the time of the battle in repair. Tree out of seven damaged tanks suffered only small harm and were urgently repaired (Kopecký, M. 2001, p. 20-23).

${ }^{21}$ VÚA-VHA, archival fund [a. f.] Československá vojenská mise v SSSR [Czechoslovak Military Mission in the USSR], box 8, inv. no. 67. 
This figure is, however, necessary to reject as excessive ${ }^{22}$ and not substantiated; the truth is much simple, nevertheless not satisfactory - fact is that real number of killed opponents remains unknown.

The evening of 5 November 1943, however, did not marked the end of combat. Initially, the commander of 51st Rifle Corps, decided that attack should went on following morning, at 6.00 a.m. Commander of 38 Army, Lt. Gen. K. Moskalenko, had, however, upper hand and at 9.00 p.m. decided to made use of fact that Germans were retreating in fast pace and thus to unfold the offensive to its successful ending; that is why his formations got an order to continue in attack.

\section{Brigade}

commander,

Col. L. Svoboda, personally met firstline units and told them the decision. The task for Czechoslovaks was to assault in line of Solomyanka (Соломянка) and Stalinka (Сталінка; today Demiivka, Деміївка) to Dnieper River. Czechoslovaks received additional ammunition and began their advancement at around 2.00 a.m. on 6 November 1943. In its beginning, Germans offered distinct resistance but

${ }^{22}$ Exaggeration about number of losses of opponents is military 'constant' and Czechoslovaks were not exception. Another argument could be the fact that if 630 killed represented only part of losses that Czechoslovak inflicted to Germans - only category 'killed in action' -, it would mean that final numbers would be three or four times higher, i.e. 1890 to 2520 men - this is in fact the whole infantry regiment. this in early morning hours got gradually fainted. So, at around 6.00 p.m. $.^{23},{ }^{24}$, Czechoslovak tanks together with sub-machine gunner reached eastern bank of Dnieper River and finished cleansing the streets of southern Kyiv from Germans; in couple of hours, also Czechoslovak infantry fulfilled its task when arrived in Stalinka ${ }^{25}$.

When Czechoslovaks reached bank of Dnieper River, they immediately got into shelling. The fire came from eastern bank of Dnieper where Soviet artillery had its positions. Czechoslovak tank battalion together with units of sub-machine guns began to shoot signal rockets, so Soviets eventually recognized their mistake and ceased their fire; Czechoslovaks were lucky once again, because incident did not take any losses (Kvapil, O. 2010, p. 252).

The battle in Kyiv, especially during afternoon and evening of 5 November 1943 and in the night to following day, was also the first experience of Czechoslovaks with urban warfare.

23 VÚA-VHA, a. f. Československé tankové jednotky v SSSR [Czechoslovak Tank Units in the USSR], box 1, inv. no. 12.

${ }^{24}$ The time the Czechoslovaks reached the Dnieper River varies according to sources. War journal of tank battalion, for example, dates that moment at 7.00 a.m. These discrepancies are not, however, extraordinary; if anything, time determination was only approximate also due to fact that wrist watches were rare among Czechoslovak soldiers and officers.

25 VÚA-VHA, a. f. 1. československá samostatná brigáda [1st Czechoslovak Independent Brigade], box 1, inv. no. 10 . 
Despite the fact that Czechoslovaks were prepared very little for combat within built-up area. In fact, the only aspect that documented that brigade would be deployed in city was assignment of engineer units in first line together with battle formations. But they achieved unprecedented success. It would not be, however, possible without Red Army pushing hard in south-west direction towards Vasylkiv (see below). So, their experience in Kyiv became for them a school of combat.

Pertaining to principles of urban warfare ${ }^{26}$ that proved its effectiveness is importance of orientation. Commanders and leaders of brigade obtained maps, but it was very difficult to navigate through destroyed city - large areas had been, according to witnesses, damaged beyond recognition. Fortunately, members of local fire department were willing to help as guides. Urban combat takes place in inhabited areas, even if sparsely; so, cooperation with civilians has its advantages. In case of Czechoslovak brigade, when tank battalion became involved in combat in Bolshevik Factory civilians were able to inform about location of German strongholds. Since urban terrain forces to split military formations into smaller units, cooperation and maintaining contact is of key importance. After all,

\footnotetext{
26 Pertaining to urban warfare and its principles, see e.g. (DiMarco, Louis A. 2012, p. 15-26; Military Operations on Urbanized Terrain (MOUT). 1998, p. 1 and following).
}

Czechoslovaks got into friendly fire at least - as documented - two times.

Also armoured vehicles demanded special use. Combat in Kyiv showed that view from inside a tank is very limited and in streets inadequate. For this reason, Lt. R. Tesařík ordered to his tank commanders to fight with open hatches (Bejček, E. \& Hanzlík, F. 2002, p. 44).

When combats finally moved into Kyiv, the situation in battlefield became for Germans critical. Decisive was expanding of Soviet offensive in direction of Vasylkiv. In that phase of battle, key significance had a moment when German defence on outer edge of city was broken and the thread of their encirclement became real. After that, German resistance became limited on local strongholds to allow for the rest of the soldiers to abandon the city. Under these circumstances, Czechoslovak as well as Soviet troops that aimed directly down the city centre were able to lead deep manoeuvres without encountering harsh resistance (Za svobodu Československa. Svazek první. 1959, p. 365).

\section{Combats in Chernyakhiv and south of Vasylkiv}

In the afternoon on 6 November 1943, 1st Czechoslovak Brigade was transferred to reserve of 38 Army and was ordered to march to village Sofiivska Borshchahivka (Софіївська Борщагівка), i.e. some $15 \mathrm{~km}$ 
westwards; so, between 6.00 p.m. and 8.00 p.m. its units assumed newly assigned positions. There, the task of Czechoslovaks was to defend against potential attacks of Germans from west and south. In a moment of their arrival, the area of their responsibility was extended to include also neighbouring village Mykilska Borshchahivka (Микільська Борщагівка).

During their stay in both Borshchahivkas, Czechoslovaks improved their trenches and fortification and were well prepared for defence. But next day they were tasked to transfer through Vasylkiv to Fastiv, i.e. nearly $70 \mathrm{~km}$ south-west. When the brigade was massed in Vayslkiv, its order was changed to stay there and to set aside a special unit that would take part in attack towards Kaharlyk (Кагарлик). It meant that the unit needed to go long distance since its goal was located $60 \mathrm{~km}$ far from Vasylkiv and in opposite direction, south-east. This newly formed troop was composed of nine tanks (two T-34 and seven T-70), submachine company and engineer platoon and as its commander was appointed Lt. Vladimír Janko, chief of staff of tank battalion ${ }^{27}$.

This ad hoc 'task force' departed at 4.00 p.m. on 8 November 1943 and following day got involved into combat in Chernyakhiv (Черняхів), ca. $20 \mathrm{~km}$ north of Kaharlyk. There,

${ }^{27}$ VÚA-VHA, a. f. 1. československá samostatná brigáda [1st Czechoslovak Independent Brigade], box 1, inv. no. 10 . at 3.00 p.m., Czechoslovaks unleash an attack together with one battalion from Soviet 342nd Rifle Regiment of 136th Rifle Division. Despite limited visibility due to fog, Czechoslovaks and the Red Army broke through German defence line and during the night repulsed opponents from the village; the cost for this victory was, however, four tanks and 29 soldiers, i.e. ten killed, 16 wounded and fate of three more soldiers remained uncertain. After midnight, the Czechoslovak unit fended off counterattack that aimed to the rear of position of Soviet rifle regiment. This fight, nevertheless, marked an end of deployment of Czechoslovaks; since only three ${ }^{28}$ tanks remained, the unit lost its operational ability as an armoured support for infantry and was sent back to brigade ${ }^{29}$.

On 9 November 1943, Germans commenced strong counterattack and forced their way up to area east of Fastiv in Fastivets (Фастівець) and Klekhivka (Клехівка) and pushed forward along road to Vasylkiv. The Czechoslovaks based their defence on northern bank of Stuhna River

28 Out of nine tanks four were destroyed and one tank broke down, but the fate of remaining last tank is not certain, probably experienced technical difficulties too (Kopecký, M. 2001, p. 24-27).

29 VÚA-VHA, a. f. Československé tankové jednotky v SSSR [Czechoslovak Tank Units in the USSR], box 1, inv. no. 12. 
(Стугна) that was strengthen with one IPTAP $^{30}$ regiment and mine field ${ }^{31}$.

In order to turn the situation in the battlefield in favour of Soviets, the brigade received an order to deliver a strike against advancing German forces. For this purpose, another 'task force' was formed. It was composed of two infantry companies, one anti-tank battery, sub-machine platoon and four middle and one light tank; its commander became Cpt. Otmar Záhora from 2nd company of II battalion. This unit was sent to Mytnytsya (Митниця) south-west of Vasylkiv with its task to attack in direction through area south-east of Kodaky (Кодаки) and Kommuna Chayka (Коммуна Чайка) $^{32}$ to khutir Petryvka (Петривка; today Chervone Pole, Червоне Поле). The task force departed at 1.30 p.m. on 11 November 1943 and shortly after that began its assault of Kommuna Chayka. The settlement was, however, empty without any German defence whatsoever, thus Czechoslovaks marched towards Petryvka; there, together with four Red Army tanks of 21st Tank Brigade moved off directly towards khutir. Combat lasted roughly two hours, but Czechoslovak and Soviet tank crew managed to expel Germans and set their defence posi-

30 Anti-tank artillery regiment (istrebitelno-protivotankovyy artilleriyskiy polk, истребительно-противотанковый артиллерийский полк).

31 VÚA-VHA, a. f. 1. československá samostatná brigáda [1st Czechoslovak Independent Brigade], box 1 , inv. no. 10 .

${ }^{32}$ Today lost settlement. tions around southern edge of Petryvka in cost of ten wounded and four killed ${ }^{33}$.

Because of this success, commander of 38 Army order to brigade to assume positions in area of Kommuna Chayka and Trostynka (Тростинка) with its task to prevent Germans to penetrate in north direction; the left wing of brigade in Trostyna was defended by II battalion together with 86th Rifle Regiment of 180th Rifle Division and the right wing around Petryvka by I battalion with 42nd Rifle Regiment of the same formation. Next day, on 12 November 1943, advanced Czechoslovak units got involved in fights in Shevchenkivka (Шевченківка), in south-west neighbourhood of Trostyna during which Czechoslovaks achieved success and parried German counterattack. The scenario was repeated on 13 November 1943 with the same result and with final cost of five killed and two missing ${ }^{34}$; that day, however, 1st Ukrainian Front finished its Kyiv Offensive Operation and switched into defensive.

Czechoslovaks losses during fights in Chernyakhiv and south of Vasylkiv were relatively low. Between 6 and 13 November, they lost 47 men in combat, i.e. 19 killed and 28 wounded, and probably more three missing; in this

${ }^{33}$ VÚA-VHA, a. f. Československé tankové jednotky v SSSR [Czechoslovak Tank Units in the USSR], box 1, inv. no. 12.

${ }^{34}$ VÚA-VHA, a. f. 1. československá samostatná brigáda [1st Czechoslovak Independent Brigade], box 1, inv. no. 10 . 
comparison, accidental poisoning that claimed 14 dead appears to be excessively high. ${ }^{35},{ }^{36}$

$$
\text { * }
$$

When Kyiv was conquered by Soviets in the morning on 6 November 1943, forces of 1st Ukrainian Front continued in their advance in southwest direction and capture Zhytomyr and Fastiv on 7 and 9 November 1943, respectively. By that time, however, Germans switched into number of tactical counter-attacks, the largest one led by 20th Panzer Grenadier Division in western direction in line of Kornyn (Корнин), Fastiv and Trypillya (Трипілля) on 8 November 1943. Even though 'panzer grenadiers' were repelled, this moment marked Clausewitz' culmination point of Soviet offensive; after all, 1st Ukrainian Front managed to advance some $150 \mathrm{~km}$ within ten days. Locally, Red Army kept initiative, but course of combats became more harsher than decisive (Das Deutsche Reich und der Zweite Weltkrieg. Band 8. Die Ostfront 1943/1944. 2007, p. 374375). That is why the mass of Czechoslovak brigade was tasked with defence

\footnotetext{
${ }^{35}$ Eighteen soldiers of tank battalion drank unspecified liquid found in abandoned German position. In past, this accident was represented as a proof of German insidiousness (intentional poisoning), but more likely it was result of confusion of anti-freeze substance for alcohol; this hypothesis, after all, supports archival documents.

${ }^{36}$ VÚA-VHA, a. f. Československé tankové jednotky v SSSR [Czechoslovak Tank Units in the USSR], box 1, inv. no. 12.
}

goals while for offensive only its smaller part — most flexible and rapid, i.e. tanks with sub-machine support - was set aside.

\section{Results and Acclaims}

In the Battle of Kyiv on 5 and 6 November 1943, the brigade lost 89 of its men ( $2.6 \%$ of initial strength). The significance of ratio loss is important when it is compared to other major combats of Czechoslovaks in the Eastern Front. In the Battle of Sokolovo, the Czechoslovak Battalion lost $14.0 \%$ out of its 973 members on 8 March $1943^{37}$ and during the Battle of Dukla Pass, the Czechoslovak Army Corps lost $4.8 \%$ out of 16,171 within the very first day of its deployment (Binar, A. 2020, p. 58). Czechoslovak Brigade, then, managed to completely fulfil all its combat tasks which is neither the case of the engagement in Sokolovo nor in Dukla Pass. From their starting point the Czechoslovak brigade managed to advance some $22 \mathrm{~km}$ before they reached the bank of Dnieper within some 21 hours, i.e. achieved a steady tempo of approximately one kilometre in one hour - the speed that has no comparison within all Czechoslovak combat experiences before final moments of the war in 1945.

The following combats in Chernyakhiv and area of Vasylkiv were only of secondary significance but Czechoslovaks achieved two tactical victories.

${ }^{37}$ VÚA-VHA, a. f. 1. československý samostatný prapor [1st Czechoslovak Independ Battalion in the USSR], box 3, inv. no. 29. 
This success, however, belonged entirely only to smaller part of Czechoslovak brigade - to tank and sub-machine companies - while the rest of the brigade remained in fact in rear.

For its participation in the battle, the brigade was decorated with Czechoslovak Medal of Bravery in Enemy's Face (Československá medaile Za chrabrost pred neprítelem) and Order of Suvorov of the Second Class, as well as 139 of its members gained medals. Three of them, company commanders Lt. J. Buršík, Lt. A. Sochor and Lt. R. Tesařík became Heroes of the Soviet Union. It all means that participation in the Battle of Kyiv was one of the most successful combats of Czechoslovak armed forces under command of the Red Army.

This assessment of Czechoslovak achievements had its reasons. Components of brigade kept close cooperation, especially between units from different military branches. Companies of tanks as well as submachine guns effectively supported the infantry when encountered harsh resistance. In these situations, the infantry led frontal assault with an aim to attract attention and potential reinforcement of opponent while tanks and sub-machine guns attack to opponent's flanks. There is, nevertheless, another reason of key importance. Since the Czechoslovak Brigade represented only small component of all forces of 1st Ukrainian Front, Czechoslovak achievement was conditional to achievements of the Red Army - that successfully made use of superiority in numbers, especially in artillery, and the element of surprise.

\section{Conclusion}

In the Battle of Kyiv, the Czechoslovak armed forces achieved their first indisputable victory in the Eastern Theatre in the course of the Second World War; their success is in sheer contrast with previous as well as following combats, not only in regard of the very speed of their advancement, but also when their low losses are taken into account. First Czechoslovak Independent Brigade belonged to formations of second wave and as such was deployed in third day of Soviet offensive after the forces of 1st Ukrainian Front broke through German defence north-west the city. Thus, on one hand, the Czechoslovaks could made use of the achievement of the Red Army and, on the other hand, they contributed - in full strength in unfolding of the left wing of decisive manoeuvre of the operation.

Apart of all political issues that battle itself was in fact just part of the fight of two totalitarian regimes over dominance in 'Zwischeneuropa' -, the participation of the Czechoslovak armed forces in the Battle of Kyiv was an integral component of their struggle for independence; even though it was misused by Soviet politics and communist propaganda. Strictly from the operational point of view, it was well done. 


\section{RESOURCES}

Bejček, E. \& Hanzlík, F. (2002). Voják se srdcem bohéma. Genmjr. Richard Tesařík [Soldier with the Heart of a Bohemian. Maj. Gen. Richard Tesařík]. Vizovice "Lípa”, 205 p.

Binar, A. (2020). Československý odboj na Východě za druhé světové války [Czechoslovak Resistance Movement in the East during the Second World War]. Brno "Univerzita obrany", 125 p.

Binar, A. (2020). Ukrajina jak prostor utváření české (československé) vojenské tradice druhé světové války [Ukraine as an Area of Formation of Czech (Czechoslovak) Military Tradition of the Second World War]. In: DROZD, R. - HALCZAK, B. Ukraińcy i ich sąsiedzi na prestrzeni wieków [Ukrainians and Their Neighbours during Centuries]. Słupsk — Warszawa "Ukraińskie Towarzystwo Historyczne w Polsce", p. 458-472.

Buršík, J. (1992). Nelituj oběti [Do not Regret Your Sacrifice]. Praha "Naše vojsko", 125 p.

Citino, R. M. (2012). The Wehrmacht Retreats. Fighting a Lost War, 1943. Lawrence "University Press of Kansas", 410 p.

Das Deutsche Reich und der Zweite Weltkrieg. Band 8. Die Ostfront 1943/1944 [Third Reich and the Second World War. Volume 8. The Eastern Front 1943 to 1944] (2007). München "Deutsche Verlags-Anstalt", 1319 p.

Dějiny druhé světové války 1939-1945. Svazek 7 [History of the Second World War, 19391945. Volume 7] (1980). Praha "Naše vojsko", 432 p.

DiMarco, Louis A. (2012). Concrete Hell. Urban Warfare from Stalingrad to Iraq. Oxford "Osprey", $232 \mathrm{p}$.

Fidler, J. (2003). Sokolovo 1943. Malý encyklopedický slovník [Sokolovo 1943. Small Encyclopaedic Dictionary]. Praha "Naše vojsko", 119 p.

Kopecký, M. (2001). 1. československá samostatná tanková brigáda v SSSR [1st Czechoslovak Independent Tank Brigade in the USSR]. Praha "MBI", 255 p.

Kvapil, O. (2010). Cesta bouř́ [Journey through the Storm]. Praha "Brána", 307 p.

Kyjev. Dukla. Praha [Kyiv. Dukla. Prague] (1975). Praha "Naše vojsko”, 331 p.

Manstein, E. (1964). von. Verlorene Siege [The Lost Victories]. Frankfurt am Main Bonn “Athenäum Verlag”, 664 p.

Maršálek, Z. (2017). “Česká”, nebo “československá” armada? Národnostní složení československých vojenských jednotek v zahraničí v letech 1939-1945 [“Czech» or “Czechoslovak» Army? Nationality Composition of Czechoslovak Military Units in Exile in 1939-1945]. Praha "Academia", 525 p.

Military Operations on Urbanized Terrain (MOUT). (1998). Washington "Headquarters United States Marine Corps", 368 p.

Moskalenko, K. S. (1972). Na yugo-zapadnom napravlenii 1943-1945 [On South-Western Direction 1943-1945]. Moskva "Nauka", 642 p.

Schramm, P. E. (2005). Kriegstagebuch des OKW. Band 3. 1943. Teilband 2 [Journal of German High Command. Volume III. 1943. Book 2]. Bonn "Bemard \& Graefe Verlag”, 1661 p. 
Směr Praha [Direction Prague] (1960). Praha "Naše vojsko", 602 p.

Svoboda, L. (1960). Z Buzuluku do Prahy [From Buzuluk to Prague]. Praha "Mladá fronta", $305 \mathrm{p}$.

The National Defence University of Ukraine named after Ivan Cherniakhovskyi. General Information. (2021). URL: https://nuou.org.ua/en/u/zv.html [Accessed: 01.04.2021].

Vališ, Z. (2013). Účast Čechoslováků při osvobozování Kyjeva v listopadu 1943 [Participation of Czechoslovaks in Liberation of Kyiv in November 1943]. Historie a vojenství, no. 3, p. 46-62.

Vojenské dějiny Československa. IV. díl (1939-1945) [Military History of Czechoslovakia. Volume IV (1939-1945)] (1988). Praha "Naše vojsko", 797 p.

Vojenské osobnosti československého odboje [Military Personalities of the Czechoslovak Resistence Movement] (2005). Praha “AVIS”, 348 p.

Vtoraya mirovaya voyna, 1939-1945 gg [The Second World War, 1939-1945] (1958). Moskva "Voennoe izdatelstvo", 930 p.

Za svobodu Československa. Svazek první [For the Independence of Czechoslovakia. First Volume] (1959). Praha "Naše vojsko", 487 p.

Zhukov, G. K. (1979). Vospominaniya i razmyshleniya. Tom 2 [Memories and Recollections. Volume 2]. Moskva "Izdatelstvo Agenstva pechati Novosti", 658 p.

\author{
Алеш Бінар \\ доктор філософії, дочуент кафедри військової \\ теорії факультету військового керівництва, \\ Університет оборони \\ (Брно, Чеська Республіка) \\ ORCID: https://orcid.org/0000-0001-8271-3730
}

\title{
УЧАСТЬ ЧЕХОСЛОВАКІВ У КИЇВСЬКІЙ БИТВІ 1943 р.
}

Битва під Києвом належить до ключових моментів історії Другої світової війни, але вона також має своє значення в чеській та чехословацькій військовій традиџї, оскільки 1-ша Чехословачька незалежна бригада брала участь у иій битві. Існування в СРСР чехословачьких збройних сил датується 1942 роком, коли перша чехословаџька військова частина була сформована поблизу Самари на території сучасної Росії. Збільшення кількості чехословаків дозволило створити самостійну бригаду в 1943 роиі; як така, бригада складалася з піхоти (два батальйони), танків (один батальйон), артилерії (два батальйони) та інших підрозділів забезпечення. Його члени представляли непослідоване по- 
єднання доль, навичок, політичних поглядів та національностей - наприклад, приблизно дві третини з них походили з територї Підкарпатської Русі (сучасна Закарпатська область). Незважаючи на цее, усі вони були віддані боротьбі за національну незалежність, а їхній бойовий дух був загалом високим.

Для наступу на Київ чехословакам було доручено здійснити штурм, як підрозділу другого порядку в лівому крилі, головного наступального напрямку. Таким чином, бригада була розгорнута протягом третього дня бою. Отже, з ранку 5 листопада 1943 р. чехословаки просувалися до Києва і близько 16:00. досягли його передмістя; тоді вони продовжсили рух до ичентру міста приблизно навколо сучасного проспекту Перемоги. Там вони брали участь у жорстоких боях, особливо на фабриці «Більшовик», кінофабриці та в районі зоопарку; крім того, батальйон брав участь у бою у складі сучасного Національного університету оборони імені Івана Черняховського. До 18:00 вони виконали своє завдання, дійшовши до району Київського вокзалу. Рано вранияі наступного дня вони просунулись далі на південний схід і близько 6:00 ранку прибули до Дніпра.

Коли Київ був звільнений, на чехословаків були покладені оборонні завдання в районі Василькова. Її два відокремлені спеціальні підрозділи танків $i$ кулеметників, а також інженери брали участь у тактичних атаках в Черняхові та на південь від Василькова, до закінчення наступу на Київ 13 листопада 1943 р. Для виконання своїх завдань чехословаки мали 136 бойових втрат в пеpiod 6-13 листопада 1943 p.

Вищезазначене означає, щуо участь 1-ї чехословацької незалежної бригади у битві під Києвом належить до одного з найуспішніших боӥв чехословацьких збройних сил на Східному фронті.

Битва під Києвом була не лише «місием пам'яті» $i$, отюе, важливою для формулювання воєнної традиції, але також мала своє місче в прочесі набуття військових навичок; бойові дї в Києві були периими випадками, коли чехословаки брали участь у міській війні. Незважаючи на те, щуо вони не тренувались для цуього і не були готові, вони досягли ряду бойових перемог, особливо завдяки тісній співпрацуі між підрозділами різних військових відділів.

Дослідження методологічно базується на процедурах архівних досліджень і як таке намагається описати хід подій; тим не менше, для иієї мети існують обмеження. Незважаючи на цее, архівні ресурси, а також спогади учасників дозволяють отримати правдивий огляд ключових моментів та представити чехословаџьку боротьбу також за принципами міської війни.

Ключові слова: битва під Києвом; 1-а Чехословаџька незалежна бригада; Східний фронт; Друга світова війна; 1943; міська війна; військова традиція. 